\title{
Kombinasi TUTORIAL DENGAN METOdE TANYA JAWAB UNTUK Meningkatkan Pemahaman Matematika di Perguruan Tinggi
}

\author{
TUTORIAL COMBINATION WITH ANSWER AND ASK QUESTION METHOD TO IMPROVE \\ MATHEMATICS UNDERSTANDING IN HIGHER EDUCATION LEVEL
}

\author{
Senja Putri Merona \\ Pendidikan Matematika, Universitas Muhammadiyah Ponorogo \\ senjaputrimerona@gmail.com
}

\begin{abstract}
Abstrak
Tujuan penelitian ini adalah untuk mendeskripsikan langkah-langkah kombinasi tutorial tambahan dengan metode tanya jawab yang dapat meningkatkan pemahaman matematika mahasiswa. Jenis penelitian ini adalah penelitian tindakan kelas dalam dua siklus. Masing-masing siklus dilaksanakan dalam 3 pertemuan. Subyek penelitian ini adalah mahasiswa Prodi Matematika FKIP Universitas Muhammadiyah Ponorogo yang memprogram matakuliah Statistika Matematika pada semester genap 2015/2016. Dari hasil penelitian diperoleh bahwa pelaksanaan tutorial dengan tanya jawab yang dapat meningkatkan pemahaman matematika siswa adalah sebagai berikut: (1) Perencanaan: pada tahap ini dosen mempelajari bahan ajar, mengidentifikasi bagian yang dirasa sulit, dan menyusun strategi pembimbingan, (2) Persiapan: pada tahap ini dosen menyiapkan bahan ajar tambahan, menyiapkan soal-soal sederhana sebagai latihan dan analogi untuk menyelesaikan permasalahan serupa yang lebih kompleks, (3) Pelaksanaan: pada tahap ini dosen mengidentifikasi dan menganalisis kesulitan mahasiswa dan melaksanakan tutorial untuk menyelesaikan kesulitan tersebut. Pelaksanaan tutorial dikombinasikan dengan tanya jawab dengan metode reinforcement dan prompting, dan (4) Evaluasi dan Penutup: pada tahap ini dosen melaksanakan konfirmasi untuk memastikan bahwa mahasiswa telah dapat mengatasi kesulitannya dan mememinta mahasiswa untuk mengerjakan tugas tambahan untuk memantapkan pemahamannya. Dari hasil tes akhir siklus diperoleh skor pemahaman matematika siswa pada siklus satu yaitu $42.86 \%$ dan $80.95 \%$ pada siklus kedua. Hal ini menunjukkan bahwa pemahaman matematika mahasiswa mengalami peningkatan.

Kata Kunci: tutorial, tanya jawab, pemahaman.
\end{abstract}

\begin{abstract}
The purpose of this study is to describe the steps the combination of additional tutorials with question and answer method can improve student understanding of mathematics. This research is a classroom action research in two cycles. Each cycle carried out in three meetings. The subjects of this study are students Prodi FKIP Mathematics, University of Muhammadiyah Ponorogo program Mathematical Statistics courses in the second semester 2015/2016. The result showed that the implementation of the tutorial by questions and answers that can improve the understanding of mathematics students are as follows: (1) Planning: at this stage lecturers studying teaching materials, identify the part that is considered difficult, and strategize guidance, (2) Preparation: on this stage lecturers prepare supplementary instructional materials, prepare questions simple as exercise and analogy to resolve similar issues are more complex, (3) Implementation: at this stage lecturer identify and analyze the difficulties students and carry out the tutorial to resolve these difficulties. Implementation tutorial combined with a question and answer with the method of reinforcement and prompting, and (4) Evaluation and Closing: at this
\end{abstract}


stage lecturers carry out a confirmation to ensure that students have been able to overcome the difficulties and mememinta students to perform additional tasks to solidify their understanding. From the end of the cycle test results obtained scores understanding of mathematics students in cycle one, namely $42.86 \%$ and $80.95 \%$ in the second cycle. This suggests that the increased student understanding of mathematics.

Keyword: tutorials, answer and ask question, understanding.

\section{Pendahuluan}

Matematika di perguruan tinggi didefinisikan sebagai ilmu dengan obyek yang abstrak. Pembelajaran matematika di perguruan tinggi berperan dalam mengembangkan pola pikir yang rasional, kemampuan analisa, ketepatan pengambilan keputusan berdasarkan argumen yang valid, dan kemampuan pengambilan keputusan. Selain itu, Anshar (2000:15) menyatakan bahwa penekanan pembelajaran matematika di perguruan tinggi dilakukan pada beberapa aspek, yaitu pemahaman konsep dengan baik dan benar, kekuatan bernalar matematika, keterampilan dalam teknik dan metode dalam matematika, dan kemampuan belajar mandiri. Martono (1999) menjelaskan tujuan pembelajaran matematika di perguruan tinggi untuk memperoleh pengetahuan dasar dan pola pikir matematika, dalam bentuk: (1) tertatanya pola pikir ilmiah yang kritis, logis, dan sistematik, (2) terlatihnya daya nalar dan kreativitas setelah mempelajari berbagai strategi dan taktik dalam pemecahan masalah kalkulus, (3) terlatih dalam merancang model matematika sederhana, (4) terampil dalam teknik matematika yang baku dengan didukung oleh konsep, penalaran, rumus, dan metode yang benar.

Salah satu aspek penting untuk mendukung tercapainya tujuan pembelajaran matematika tersebut yaitu pemahaman konsep. Dengan pemahaman matematika yang baik, pola pikir mahasiswa akan terbentuk secara sistematis dan logis. Hal ini berimplikasi pada terfasilitasinya daya nalar dan kreatifitas dalam pemecahan masalah.

Faktanya, pemahaman mahasiswa terhadap konsep-konsep matematika ratarata masih rendah. Hal ini diketahui dari hasil observasi awal yang dilakukan pada matakuliah Kalkulus Peubah Banyak. Pada topik turunan fungsi dua variabel, pemahaman mahasiswa masih kurang. Sebagai contoh, mahasiswa salah dalam menerapkan teorema turunan dengan satu variabel ke dalam masalah turunan dengan dua variabel. Kondisi ini memaksa dosen untuk kembali mengulang beberapa konsep turunan satu variabel. Hal ini meyebabkan target perkuliahan tidak tercapai sesuai yang direncanakan.

Pemahaman mahasiswa tidak dapat ditanamkan dalam waktu yang singkat. Di satu sisi, waktu perkuliahan yang terbatas membuat pembelajaran di kelas tidak maksimal. Untuk memenuhi target perkuliahan yang telah disusun, 
mahasiswa perlu belajar secara mandiri. Ketika mahasiswa belajar secara mandiri, mereka masih mengalami beberapa kesulitan. Ketika mengalami kesulitan atau muncul pertanyaan, mahasiswa cenderung mencari tempat untuk bertanya, baik kepada sesama mahasiswa atau kepada dosen. Oleh karena itu, mahasiswa masih memerlukan bimbingan dari teman sebaya dan dosen. Pemberian kelas tutorial tambahan diharapkan dapat memfasilitasi mahasiswa untuk memperdalam pemahamannya. Selain itu, metode tanya jawab memungkinkan mahasiswa untuk saling bertukar informasi untuk membangun pemahamannya. Kombinasi antar keduanya dapat memperkuat pemahaman matematika mahasiswa tentang materi yang telah disampaikan dalam kelas perkuliahan reguler.

Pemahaman dapat didefinisikan sebagai ukuran kualitas dan kuantitas koneksi yang dimiliki suatu ide dengan ide lain yang telah ada (Van De Walle, 2007: 26). Pemahaman matematika merupakan proses untuk menempatkan informasi atau pengetahuan yang sedang dipelajari kemudian mengaitkan dengan pengetahuan yang sudah dimiliki sebelumnya (Hiebert dan Carpenter, 1992: 70). Kegiatan yang dilakukan untuk dapat memahami adalah kegiatan mental intelektual yang mengorganisir materi yang telah diketahui. Informasi-informasi seperti fakta, konsep, definisi, dan prinsip disusun kembali dalam struktur kognitif yang ada. Skemp (1975: 153) membedakan dua jenis pemahaman, yaitu pemahaman instrumental dan pemahaman relasional. Selanjutnya Skemp (1975: 155) menjelaskan bahwa siswa dengan pemahaman instrumental hanya melakukan prosedur untuk mendapatkan jawaban tanpa mengetahui alasan dan penjelasannya. Sebaliknya, pemahaman relasional atau sering disebut pemahaman konseptual adalah pemahaman tentang struktur pengetahuan yang saling berhubungan dan dapat digunakan untuk penyelesaian masalah yang lebih luas dan komplek.

Menurut Kamus Besar Bahasa Indonesia, tutorial berarti pembimbingan kelas oleh seorang pengajar (tutor) untuk seorang mahasiswa atau sekelompok kecil mahasiswa; pengajaran tambahan melalui tutor. Sedangkan tutor sendiri menurut Kamus Besar Bahasa Indonesia adalah orang yang memberi pelajaran (membimbing) kepada seseorang atau sejumlah kecil siswa (di rumah, bukan di sekolah); dosen yang membimbing sejumlah mahasiswa dalam pelajarannya. Secara khusus, metode tutorial dapat diartikan sebagai suatu proses pembelajaran yang dilakukan melalui proses bimbingan yang diberikan oleh dosen kepada mahasiswa baik secara perorangan atau kelompok kecil.

Pembelajaran dengan metode tutorial mencakup langkah-langkah sebagai berikut.

1. Langkah Perencanaan, mencakup mempelajari modul, mengidentifikasi bagian-bagian yang sulit, dan menyusun strategi bimbingan. 
2. Langkah Persiapan, mencakup menyiapkan bahan ajar tambahan, menyiapkan soal-soal sederhana sebagai jembatan untuk menyelesaikan soal-soal yang sulit.

3. Langkah Pelaksanaan, mencakup mengidentifikasi kesulitan yang dihadapi siswa, melaksanakan tutorial.

4. Langkah Evaluasi dan Penutup, mencakup melakukan tanya jawab untuk meyakinkan bahwa siswa yang bersangkutan telah dapat mengatasi kesulitan belajarnya dan memahami materi pembelajaran yang dipelajari, memberikan tugas mandiri, termasuk mempelajari tugas tambahan dengan tujuan memantaapkan dan memperluas pemahaman siswa yang bersangkutan tentang materi yang dipelajari.

Metoda tanya jawab adalah metoda pembelajaran di mana materi ajar disampaikan dalam bentuk tanya jawab antara guru dengan siswa dan sesama siswa (Gintings, 2008: 45). Keberhasilan penggunakan metoda tanya jawab dalam kegiatan pembelajaran sangat ditentukan oleh penguasaan teknik atau keterampilan guru dalam menyampaikan dan menjawab pertanyaan.

Untuk mensiasati penggunaan metode tanya jawab, ada beberapa strategi yang dapat dilakukan yaitu: (1) Phrasing; penggunaan kalimat tanya yang jelas, singkat, tidak mengaburkan pikiran, dan menggunakan kata-kata sederhana yang mudah dipahami oleh siswa; (2) Focusing; memusatkan perhatian siswa ke arah jawaban yang diminta oleh sang penanya; (3) Pausing; memberi kesempatan sejenak kepada siswa untuk menyusun jawabannya; (4) Reinforcement; memberi reward/penghargaan sebagai motivasi atau dorongan kepada siswa yang bertanya; (5) Promting; memancing siswa dengan pertanyaan lain agar terbimbing dalam menemukan jawaban dari pertanyaan terdahulu; (6) Probing (pelacakan); mengajukan pertanyaan yang bersifat melacak, yakni mengikuti respon siswa kemudian merangsang siswa untuk memikirkan jawaban yang telah mereka ajukan dengan maksud untuk mengembangkan jawaban terdahulu agar lebih jelas dan akurat.

Memperhatikan keunggulan dan kelemahan masing-masing metode, kombinasi tutorial dengan tanya jawab dirancang agar metode yang dihasilkan dapat meningkatkan pemahaman matematika siswa sebagai berikut.

1. Kelas tutorial dilaksanakan di luar jam perkuliahan normal sebagai jam kuliah tambahan

2. Mahasiswa diwajibkan mempelajari materi yang telah disampaikan pada jam kuliah dan mengidentifikasi kesulitan yang dialami selama perkuliahan terkait materi.

3. Kelas tutorial bersifat tanya-jawab antar dosen dan mahasiswa yang bertujuan menyelesaikan kesulitan yang dihadapi mahasiswa. 
Jika dalam satu pertemuan tidak ada pertanyaan dari mahasiswa, dosen sudah siap dengan penguatan materi prasyarat yang dibutuhkan mahasiswa untuk mempelajari materi selanjutnya di jam kuliah normal.

\section{Metode}

Penelitian ini merupakan jenis penelitian tindakan kelas (Classroom Action Research). Model PTK yang digunakan mengacu pada model PTK yang dikembangkan oleh Mertler dan Charles (dalam Mertler, 2014). Model ini meliputi 4 tahap yang membentuk siklus, yaitu (1) perencanaan, (2) tindakan, pengembangan, dan (4) refleksi. Penelitian ini direncanakan terdiri dari minimal 2 siklus. Masing-masing siklus terdiri dari 3 pertemuan dengan alokasi waktu tiap pertemuan $3 \times 45$ menit.

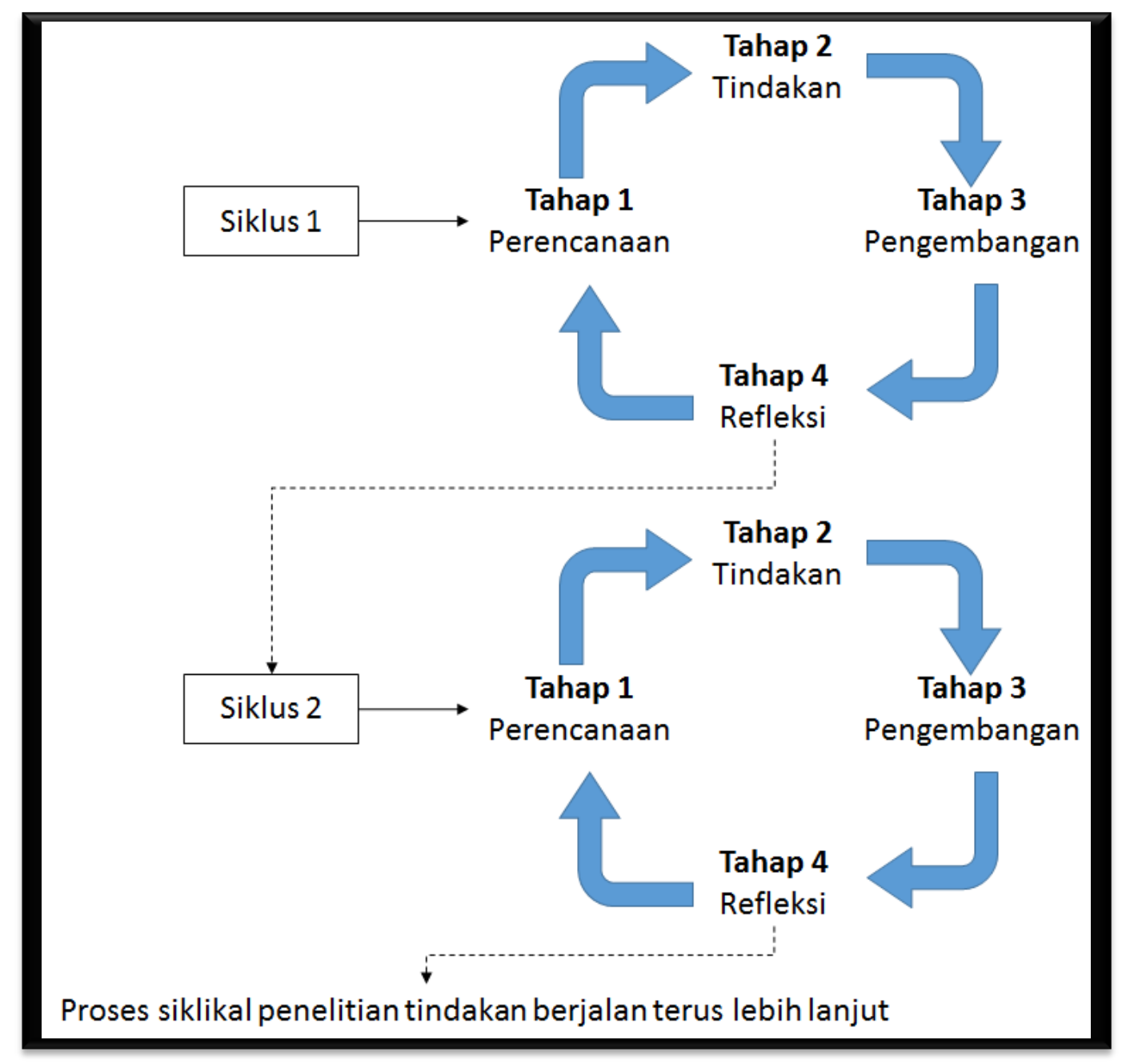

Gambar 1. Langkah-langkah Penelitian yang diadaptasi dari Mertler dan Charles (2014).

Penelitian ini akan dilaksanakan di yang beralamat di Jalan Budi Utomo Universitas Muhammadiyah ponorogo Nomor 10, Ponorogo. Subyek penelitian ini 
adalah mahasiswa program sudi pendidikan matematika FKIP Universitas Muhammadiyah Ponorogo yang memprogram Statistika Matematika pada semester genap 2015/2016.

Data yang diperlukan dalam penelitian ini adalah data pemahaman matematika mahasiswa. Data yang dikumpulkan dalam penelitian ini adalah (1) hasil tes, (2) hasil wawancara dengan subyek penelitian, (3) hasil observasi aktivitas dosen, (4) hasil observasi aktivitas mahasiswa. Data yang dikumpulkan berupa hasil tulisan maupun lisan yang direkam selama proses pembelajaran. Pengumpulan data pada penelitian ini dilakukan melalui observasi, tes, dan wawancara.

Teknik analisis data pada penelitian ini menggunakan analisis kualitatif dan kuantitatif. Analisis data kualitatif yang dilakukan adalah analisis induktif yang dikemukakan oleh Parson dan Brown (dalam Mertler, 2014: 173) yang meliputi 3 langkah, yaitu organisasi, deskripsi, dan interpretasi. Sedangkan analisis data kuantitatif dilakukan untuk memperoleh statistic deskriptif dari hasil tes pemahaman mahasiswa, data hasil observasi aktivitas dosen, dan data hasil observasi aktivitas mahasiswa.

Suatu siklus dikatakan berhasil jika memenuhi kriteria keberhasilan tindakan yang telah ditentukan. Kriteria keberhasilan tindakan pada penelitian ini adalah sebagai berikut: (1) minimal 75\% siswa mencapai nilai ketuntasan belajar minimal, yaitu 60 yang diukur dari tes akhir siklus dan diperkuat melalui wawancara, (2) hasil observasi aktivitas guru minimal berada pada kategori baik, dan (3) hasil observasi aktivitas siswa minimal berada pada kategori baik.

\section{Hasil dan Pembahasan}

Observasi awal memberikan informasi tentang karakteristik dan kemampuan awal mahasiswa. Mahasiswa tergolong kritis dan sangat terbuka dalam mengungkapkan pendapatnya. Dari aspek kemampuan awal, tidak lebih dari $25 \%$ mahasiswa yang memiliki kemampuan awal yang tinggi, namun hal ini dapat terkejar dengan rasa keingintahuan dan sikap kritis mereka. Kondisi perkuliahan dalam kelas cenderung ramai dan tidak kondusif.

Pada siklus pertama, tindakan dilaksanakan dalam 5 kali pertemuan dengan materi peubah acak diskret dan kontinu, distribusi bersama, dan distribusi bersyarat. Dari tindakan selama 5 pertemuan, peneliti menganalisis materi apa yang masih dirasa sulit dipahami oleh mahasiswa. Dari hasil analisis, diperoleh informasi bahwa kesulitan mahasiswa adalah dalam membedakan jenis-jenis distribusi peubah acak.

Tutorial dirancang dengan fokus utama yaitu memahamkan mahasiswa mengenai karakteristik utama masing-masing jenis distribusi peubah acak. Pada tahap persiapan, peneliti menyiapkan soal-soal sederhana sebagai analogi dari masingmasing jenis distribusi peubah acak. Selanjutnya, tahap pelaksanaan tutorial dilakukan pembahasan soal-soal yang 
telah disiapkan. Penliti memberi ruang dan waktu seluas-luasnya untuk mahasiswa bertanya. Dalam proses tanya jawab, peneliti menggunakan strategi reinforcement dan prompting. Sebelum peneliti menjawab pertanyaan yang muncul, pertanyaan ditawarkan terlebih dahulu untuk dijawab oleh mahasiswa yang lain. peneliti memberikan reward bagi mahasiswa yang bertanya maupun menjawab pertanyaan. Peneliti juga memberikan pertanyaan-pertanyaan membimbing untuk mengarah ke jawaban pertanyaan awal. Tutorial diakhiri dengan evaluasi. Pada tahap ini peneliti memberikan penguatan dan konfirmasi terhadap materi yang dibahasa pada tutorial ini. Peneliti juga memberikan motivasi untuk mempelajari kembali materi yang telah disampaikan dengan tujuan memantapkan pemahaman mahasiswa.

Siklus pertama diakhiri dengan tes akhir siklus I. Hasil tes menunjukkan hanya 9 dari 21 anak yang mencapai nilai lebih dari atau sama dengan 60. Berdasarkan hasil refleksi, diperoleh hal-hal yang menjadi hambatan dalam pelaksanaan siklus pertama. Hambatan tersebut antara lain adalah (1) tidak seluruh soal yang disiapkan dapat terbahas, (2) pertanyaan yang muncul dari mahasiswa tidak sepenuhnya mewakili materi yang dibahas, (3) mahasiswa masih lemah di bagian pengetahuan prasyarat, seperti teknik integrasi, dan (4) cakupan materi terlalu luas sehingga mahasiswa kesulitan dalam memahami materi.
Pada siklus kedua, dilakukan beberapa perbaikan berdasarkan hasil refleksi siklus pertama. Peneliti membatasi cakupan materi, yaitu: ekspektasi, variansi dan standar deviasi, kovarian dan korelasi. Peneliti juga memberikan penekanan pada pengetahuan prasyarat. Selain itu, peneliti juga menyiapkan soal-soal latihan dengan alokasi waktu yang disesuaikan.

Pelaksanaan tindakan difokuskan pada penyampaian materi oleh dosen untuk mencapai target pemahaman matematika mahasiswa. Dari perkuliahan selama 3 pertemuan, kesulitan yang dialami siswa adalah pada saat membuktikan sifat-sifat ekspektasi, variansi, standar deviasi, kovarian, dan korelasi. Dari sini peneliti mengembangkan rencana tindakan ke arah tutorial dengan fokus utama adalah memperkuat kemampuan menyusun bukti teorema.

Pada tahap persiapan peneliti menyiapkan soal-soal terkait pembuktian ekspektasi dari peubah acak khusus. Selanjutnya, tahap pelaksanaan tutorial dilakukan pembahasan soal-soal yang telah disiapkan. Penliti memberi ruang dan waktu seluas-luasnya untuk mahasiswa bertanya. Dalam proses tanya jawab, peneliti menggunakan strategi prompting. Sebelum peneliti menjawab pertanyaan yang muncul, pertanyaan ditawarkan terlebih dahulu untuk dijawab oleh mahasiswa yang lain. Peneliti juga memberikan pertanyaan-pertanyaan membimbing untuk mengarah ke jawaban pertanyaan awal. Tutorial diakhiri dengan evaluasi. Pada tahap ini peneliti 
memberikan penguatan dan konfirmasi terhadap materi yang dibahasa pada tutorial ini. Peneliti juga memberikan motivasi untuk mempelajari kembali materi yang telah disampaikan dengan tujuan memantapkan pemahaman mahasiswa.

Siklus kedua ditutup dengan tes akhir siklus II. Hasil tes menunjukkan bahwa 17 dari 21 anak yang mencapai nilai lebih dari atau sama dengan 60. Meskipun belum seluruh mahasiswa dapat mencapai standar minimum yang ditetapkan oleh peneliti, namun hasil ini telah memenuhi kriteria keberhasilan penelitian. Presentase banyaknya mahasiswa yang mencapai nilai 60 naik dari 42.86\% pada siklus pertama menjadi $80.95 \%$ pada siklus kedua.

Beberapa kendala masih ditemui dalam penerapan metode ini, diantaranya adalah sulitnya mengatur jadwal di luar jam perkuliahan yang disepakati oleh dosen dan mahasiswa. Terbatasnya waktu yang dimiliki oleh dosen dan padatnya jadwal kuliah mahasiswa sendiri menjadi penyebab hambatan ini. Selain itu, alokasi waktu selama tutorial yang terbilang singkat belum cukup mengakomodir kesulitan siswa. Metode pembelajaran selama tutorial juga dirasa perlu dipertimbangkan kembali untuk lebbih mengoptimalkan pengaruh atau efek dari pelaksanaan tutorial.

\section{Penutup}

Berdasarkan hasil penelitian yang telah dilaksanakan, disimpulkan bahwa pelaksanaan tutorial dengan tanya jawab yang dapat meningkatkan pemahaman matematika mahasiswa adalah sebagai berikut:

1. Perencanaan, pada tahap ini dosen mempelajari bahan ajar, mengidentifikasi bagian yang dirasa sulit, dan menyusun strategi pembimbingan.

2. Persiapan, pada tahap ini dosen menyiapkan bahan ajar tambahan, menyiapkan soal-soal sederhana sebagai latihan dan analogi untuk menyelesaikan permasalahan serupa yang lebih kompleks.

3. Pelaksanaan, pada tahap ini dosen mengidentifikasi dan menganalisis kesulitan mahasiswa dan melaksanakan tutorial untuk menyelesaikan kesulitan tersebut. Pelaksanaan tutorial dikombinasikan dengan tanya jawab dengan metode reinforcement dan prompting.

4. Evaluasi dan Penutup, pada tahap ini dosen melaksanakan konfirmasi untuk memastikan bahwa mahasiswa telah dapat mengatasi kesulitannya dan meminta mahasiswa untuk mengerjakan tugas tambahan untuk memantapkan pemahamannya.

Dari hasil penelitian diperoleh bahwa pemahaman matematika mahasiswa naik dari $42.86 \%$ pada siklus pertama menjadi 80.95\% pada siklus kedua. Hal ini menunjukkan bahwa pemahaman matematika mahasiswa mengalami peningkatan. 
Daftar Pustaka

Anshar, M dan Sembiring RK. 2000. Hakekat Pembelajaran Matematika di Perguruan Tinggi. Jakarta: Direktorat Jenderal Pendidikan Tinggi, Depdiknas Gintings, Abdorrakhman, 2008, Essensi Praktis Belajar dan Pembelajaran, Bandung: Humaniora.

Hiebert, J. \& Carpenter,T.P. 1992. Learning \& Teaching with Understanding. Handbook of Research on Mathematics Teaching and Learning. New York: Mcmillan Publishing Company.
Kamus Besar Bahasa Indonesia (http://kbbi.web.id/tutor)

Kamus Besar Bahasa Indonesia (http://kbbi.web.id/tutorial)

Martono, K. 1999. Kalkulus. Jakarta: Erlangga

Mertler, C. A. 2014. Penelitian Tindakan Kelas: Meningkatkan Sekolah dan Memberdayakan Pendidik, Edisi Ketiga. Jakarta: PT. Indeks.

Skemp, R. R. 1987. The Psychology of Learning Mathematics. Hillsdale, New Jersey: Lawrence Erlbaum Associates, Publishers. 
This page is intentionally left blank 